\title{
Article/Artigo
}

\section{One-year cardiac morphological and functional evolution following permanent pacemaker implantation in right ventricular septal position in chagasic patients}

\author{
Evolução funcional e morfológica cardíaca um ano após o implante de marcapasso definitivo \\ na posição ventricular direita septal em pacientes chagásicos
}

\author{
Otaviano da Silva Júnior ${ }^{1,2}$, Paula Mayumi Maeda ${ }^{3}$, Maria Cândida Calzada Borges ${ }^{4}$, Celso Salgado de Melo ${ }^{2}$ \\ and Dalmo Correia ${ }^{5}$
}

\section{ABSTRACT}

Introduction: The septal position is an alternative site for cardiac pacing $(\mathrm{CP})$ that is potentially less harmful to cardiac function. Methods: Patients with Chagas disease without heart failure submitted to permanent pacemaker (PP) implantation at the Clinics Hospital of the Triangulo Mineiro Federal University (UFTM), were selected from February 2009 to February 2010. The parameters analyzed were ventricular remodeling, the degree of electromechanical dyssynchrony (DEM), exercise time and $\mathrm{VO} 2$ max during exercise testing (ET) and functional class (NYHA). Echocardiography was performed 24 to $48 \mathrm{~h}$ following implantation and after one year follow-up. The patients were submitted to ET one month postprocedure and at the end of one year. Results: Thirty patients were included. Patient mean age was $59 \pm 13$ yearsold. Indication for PP implantation was complete atrioventricular (AV) block in 22 (73.3\%) patients and $2^{\text {nd }}$ degree AV block in the other eight $(26.7 \%)$. All patients were in NYHA I and no changes occurred in the ET parameters. No variations were detected in echocardiographic remodeling measurements. Intraventricular dyssynchrony was observed in $46.6 \%$ of cases and interventricular dyssynchrony in $33.3 \%$ of patients after one year. Conclusions: The findings of this work suggest that there is not significant morphological and functional cardiac change following pacemaker implantation in septal position in chagasic patients with normal left ventricular function after one year follow-up. Thus, patients may remain asymptomatic, presenting maintenance of functional capacity and no left ventricular remodeling.

Keywords: Pacemaker. Chagas disease. Septal stimulation. Left ventricular function.

\section{RESUMO}

Introdução: A posição septal representa um sítio alternativo de estimulação cardíaca artificial (ECA) potencialmente menos deletério para a função cardíaca. Métodos: Pacientes chagásicos sem insuficiência cardíaca submetidos a implante de marcapasso definitivo (MP) no Hospital de Clínicas da Universidade Federal do Triângulo Mineiro (UFTM) foram selecionados no período de fevereiro de 2009 a fevereiro de 2010. Os parâmetros analisados foram o remodelamento ventricular, o grau de dessincronia eletromecânica (DEM), tempo de exercício e VO2 máximo no teste ergométrico (TE) e a classe funcional (NYHA). O ecocardiograma foi realizado 24 a $48 \mathrm{~h}$ após o implante e após um ano de seguimento. Os pacientes foram submetidos ao TE um mês após o procedimento e ao final de um ano. Resultados: Foram incluídos 30 pacientes. A idade média foi de $59 \pm 13$ anos. A indicação do implante de MP foi bloqueio atrioventricular (BAV) total em $22(73,3 \%)$ pacientes e BAV do $2^{\circ}$ grau nos outros $8(26,7 \%)$. Todos os pacientes permaneceram em NYHA I e não houve mudança nos parâmetros do TE. Não foram detectadas variações nas medidas ecocardiográficas de remodelamento. Foi observada DEM intraventricular em 46,6\% dos casos e interventricular em 33,3\% dos pacientes ao final de um ano. Conclusões: Os achados deste trabalho sugerem que não houve mudanças morfológicas ou funcionais cardíacas significativas após o implante de marcapasso na posição septal em pacientes chagásicos com função ventricular esquerda normal após um ano de seguimento. Desta forma, os pacientes podem permanecer assintomáticos, com a manutenção da capacidade funcional e sem remodelamento ventricular esquerdo.

Palavras-chaves: Marcapasso cardíaco. Doença de Chagas. Estimulação septal. Função ventricular esquerda.

1.Programa de Pós-Graduação em Medicina Tropical e Infectologia, Universidade Federal do Triângulo Mineiro, Uberaba, MG. 2. Serviço de Estimulação Cardíaca Artificial, Hospital de Clínicas, Universidade Federal do Triângulo Mineiro, Uberaba, MG. 3. Curso de Graduação em Medicina, Universidade Federal do Triângulo Mineiro, Uberaba, MG. 4. Disciplina de Cardiologia, Universidade Federal do Triângulo Mineiro, Uberaba, MG. 5. Disciplina de Doenças Infecciosas e Parasitárias, Universidade Federal do Triângulo Mineiro, Uberaba, MG. Address to: Dr. Otaviano da Silva Júnior. Rua Constituição 730, Bairro Abadia, 38025-110 Uberaba, MG, Brasil.

Phone: $55343332-9133$

e-mail: osilvajr@hotmail.com

Received in $21 / 11 / 2011$

Accepted in 30/03/2012

\section{INTRODUCTION}

Chagas disease has afflicted humans for at least 9,000 years and has been endemic for 200 to 300 years, even though the first official description only occurred in $1909^{1,2}$. Despite the enormous effort dedicated to controlling its transmission and treatment, the disease still represents one of the most serious medical-social problems of Latin America ${ }^{3,4}$.

Chagasic cardiomyopathy is one of the most serious complications of the disease and is associated with high morbidity and mortality. Considering the pathophysiology of Chagas disease, compromise of the cardiac stimulant complex is a common finding and an evolutionary marker of worse prognosis ${ }^{5}$.

The most severe and potentially fatal lesions of the conduction system are $2^{\text {nd }}$ degree atrioventricular (AV) block and third degree AV block (complete AV block). These forms of bradyarrhythmia are usually accompanied by symptoms of low cerebral or cardiac output and are frequently associated with a very low heart rate and risk of sudden death ${ }^{6,7}$. Complete AV block is undoubtedly an unfavorable factor if left untreated, with a survival of a few weeks to a maximum of four years following diagnosis, as previously reported ${ }^{6,8,9}$. The control of bradyarrhythmias by cardiac pacing represents a significant advance in improving the prognosis of patients with Chagas disease ${ }^{8}$.

In Latin America and particularly in Brazil, bradyarrhythmias resulting from the involvement of the conduction system in chagasic myocardiopathy are one of the principal indications for permanent pacemaker implantation, since the first procedure performed in $1960^{10-12}$.

Current estimates suggest 4 to 6 million people are affected by Chagas disease in Brazil ${ }^{13,14}$. This etiology is of one the main indications for permanent pacemaker implantation in some regions, such as the Triangulo Mineiro region in Minas Gerais and the State of Goiás ${ }^{15-17}$. A similar situation is observed in other Latin American countries like Bolivia, where 
it has been reported that $60 \%$ of patients submitted to permanent pacemaker implants have Chagas disease ${ }^{18}$.

Since the beginning of endocardial pacing in 1958 and for more than four decades, the region of the right ventricle (RV) apex has been used to position the electrode, for ease of access and lower complications rates ${ }^{19,20}$. However, the stimulation site alters the physiological sequence of cardiac electrical activation and can be associated with harmful effects.

A narrow QRS complex is essential for cardiac output and its extension promotes impairment of ventricular function ${ }^{21}$. Conventional cardiac pacing with an electrode implanted on the RV apex causes important QRS enlargement accompanied by mechanical dyssyncronization of the left ventricular walls ${ }^{22}$.

Since the 1980s, evidence of the harmful effects of RV apical pacing related to the long-term effects on cardiac structure and function has been reported ${ }^{23-26}$. High levels of stimulation in the ventricular channel may lead to undesirable left ventricular remodeling, with consequent increased morbidity and mortality, particularly in patients presenting systolic dysfunction ${ }^{27}$.

In the last 12 years, several studies have been conducted in order to seek alternative sites to implant the electrode in RV endocardial pacing. The region of the bundle of His (para-His), the right ventricle outflow tract (RVOT) and the septal region (septal) have all been evaluated ${ }^{28,29}$. In Brazil, Jatene and Korman ${ }^{30}$ described a technique of implantation in the region of the RV inflow tract as an alternate site in Chagas disease, due to the cardiac structural changes observed at the RV apex in these patients.

Septal stimulation represents a simple alternative, with no extra cost and potential advantages over other sites, since the QRS complex obtained in this position is more physiologically normal in relation to electrical axis and length ${ }^{31-34}$. Nonetheless, most studies involve a small patient sample with no randomization and the criteria used to define the stimulation site can result in the evaluation of heterogeneous groups. Similarly, different methods have been used to evaluate the functional consequences of cardiac pacing and none of the study designs published so far reported research on patients with Chagas disease ${ }^{29}$.

Thus, despite demonstrations of the harmful effects of RV apical pacing and the potential benefits of alternative sites, conflicting results exist in the literature and the place of choice for implanting the right ventricular electrode has yet to be defined ${ }^{35}$. Moreover, the impact of alternative sites for endocardial pacing has not been prospectively evaluated in Chagas cardiomyopathy.

The present study aimed to prospectively evaluate the cardiac morphological and functional evolution following permanent pacemaker implantation in right ventricular septal position in chagasic patients without heart failure. This evaluation was done through clinical follow-up, physical capacity evaluation using the exercise treadmill test and quantification of echocardiographic parameters of left ventricular remodeling and mechanical dyssynchrony.

\section{METHODS}

Patients with Chagas disease submitted to permanent pacemaker implantation in the Cardiac Pacing Service of the Clinics Hospital of the Triângulo Mineiro Federal University (CH-UFTM), with the right ventricular electrode placed in the septal position, under a regime of free demand, from February 2009 to February 2010 and who met the inclusion criteria were included in the study.

The inclusion criteria were: age between 18 and 75 yearsold, positive serology for Chagas disease, patients with classic indications for implantation of a dual chamber pacemaker with high probability of right ventricular pacing ( $2^{\text {nd }}$ degree AV block or complete AV block).The exclusion criteria were: presence of heart failure or systolic dysfunction (left ventricle ejection fraction - LVEF $<55 \%$ ); another significant structural heart disease (valvular heart disease associated with heart disease, ischemic cardiomyopathy, hypertensive cardiomyopathy, restrictive cardiomyopathy) and conditions associated with cardiac pacing (stimulation index of ventricular channel $<90 \%$, development of chronic or persistent atrial fibrillation).

The pacemaker system was composed of active fixation electrodes topped on the tip by steroids and generators equipped with sensor frequency response.

The right ventricular septal position was obtained with the aid of radiological anatomy through the technique described by Liebermann et al. ${ }^{36}$ and supplemented by Kaye et al. ${ }^{37}$ (Figures 1A and 1B). Three radiological incidents were used: postero anterior (PA), $10^{\circ}$

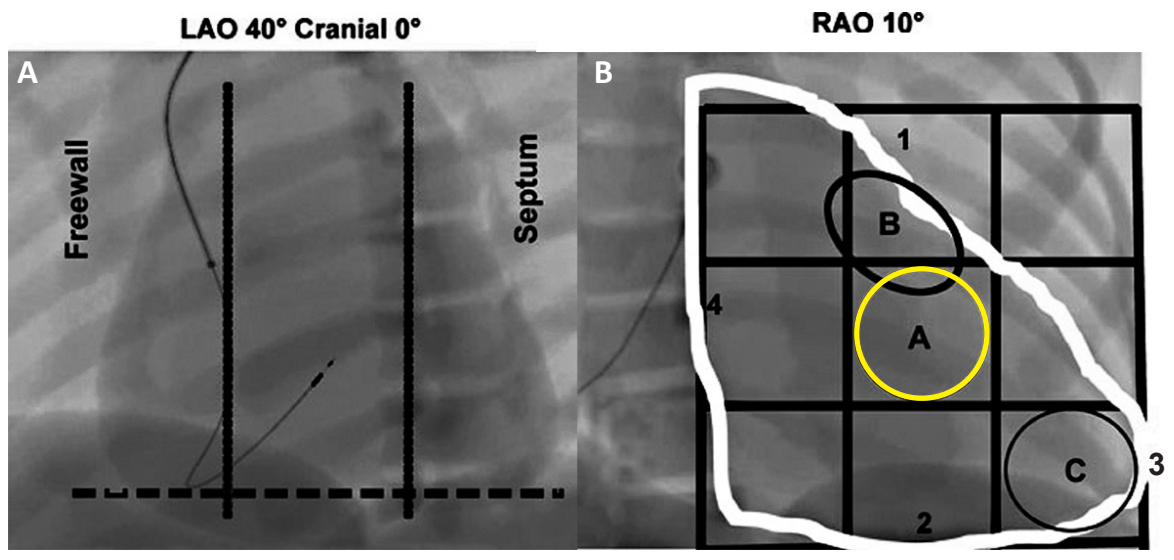

FIGURE 1 - A: $40^{\circ}$ LAO fluoroscopy with the lead in septal position. The tip of the lead is geared for the column, in a direction opposite to the freewall of the RV. B: Septal position is represented in the $10^{\circ}$ RAO fluoroscopy in accordance with the criteria used in the studies Protect Pace and Optmize RV.

The letter A (yellow circle) represents the middle portion of the interventricular septum. The methodology uses a $3 \times 3$ grid for cardiac regions division and standardization of the implant site. The letter B (circle) represents the septal region high and the letter C (circle) the tip of RV. LAO: left anterior oblique; RV: right ventricular; RAO: right anterior oblique. Source: Lieberman et al (2004) and Kaye et al (2009). 
right anterior oblique (RAO), and $40^{\circ}$ left anterior oblique (LAO) fluoroscopic.

The patients were submitted to echocardiography (ECHO) within the first $24 \mathrm{~h}$ to $48 \mathrm{~h}$ of pacemaker implantation and after one year follow-up. The parameters of left ventricular remodeling were analyzed: left ventricle end-diastolic diameter (LVEDD); end-systolic volume (ESV) and ejection fraction (LVEF) using the Simpson's rule method.

Mechanical dyssynchrony was assessed using the following variables: $\mathrm{M}$ mode (septal-to-posterior wall motion delay- SPWMD) and pulsed Doppler (left ventricular pre-ejection time - LVET; calculation of the difference between LVET and right ventricular pre-ejection time-RVET).

The exercise test (ET) was performed one month after the procedure and at the end of one year follow-up. The quantified variables were exercise duration and estimated maximum oxygen consumption $\left(\mathrm{VO}_{2} \max \right)$.

For statistical analysis, parametric test (Student $\mathrm{t}$ test) was used according to the normal distribution in the Shapiro-Wilk test and Levene's homogeneity test. Results were expressed as mean \pm standard deviation (SD). The level of significance to consider as relevant associations was $\mathrm{p}<0.05$ and confidence interval of 0.95 .

The software used was the Statistica version 9.0 (Statsoft ${ }^{\circledR}$, USA).

\section{Ethical considerations}

This study was approved by the Research Ethics Committee of the UFTM under protocol no. 1325.

\section{RESULTS}

Thirty patients were included, 18 (60\%) males and $12(40 \%)$ females, with a mean age of $59 \pm 13$ years-old. The indication for pacemaker implantation was complete AV block in 22 (73.3\%) patients and $2^{\text {nd }}$ degree AV block in the other 8 (26.7\%) patients.

The average duration of the QRS complex was $107 \pm 13 \mathrm{~ms}$ in the preimplantation period and $134.2 \pm 12 \mathrm{~ms}$ after a year of $\mathrm{PP}(\mathrm{p}<0.01)$, representing a significant broadening due to pacing (Figura $\mathbf{2 A}$ ). All the patients presented high stimulation levels in the ventricular channel throughout the monitoring period. The indices of ventricular pace was $98 \pm 2 \%$ (24-48h post implant) and $97 \pm 3 \%$ in the final evaluation after a year $(\mathrm{p}=0,84)$ (Figura 2B).

All patients were classified as functional class I (NYHA) 24-48h post implant and remained so after one year of follow-up. Likewise, no signs or symptoms of heart failure and no hospitalizations were reported related to this syndrome.
Regarding the ET parameters, the functional capacity of all patients was normal, with a mean $\mathrm{VO} 2$ max of $30.14 \pm 3 \mathrm{~mL} / \mathrm{kg} / \mathrm{min}$ one month following implantation and $29.83 \pm 3 \mathrm{~mL} / \mathrm{kg} / \mathrm{min}$ at the end of one year $(p=0.71)$. Exercise duration in the modified Bruce protocol was $12.51 \pm 2 \mathrm{~min}$ in the first assessment and $13.37 \pm 2 \mathrm{~min}$ after one year $(\mathrm{p}=0.83)$ (Table 1$)$.

No significant changes were observed in measurements indicative of ventricular remodeling (LVEDD, ESV and LVEF) after one year of cardiac pacing. Intraventricular dyssynchrony (LVET $>140 \mathrm{~ms}$ ) was detected in $43.3 \%$ of patients $24-48$ h post implant and in $46.6 \%$ of cases after one year $(\mathrm{p}=0.81)$ and interventricular dyssynchrony (LVET-RVET $>30 \mathrm{~ms}$ ) in $30 \%$ of patients $24-48 \mathrm{~h}$ pos implant and $33.3 \%$ of cases in the final measure $(\mathrm{p}=0.77)$. There was not difference between the degree of dyssynchrony comparing post implant and after one year measures (Table 2).

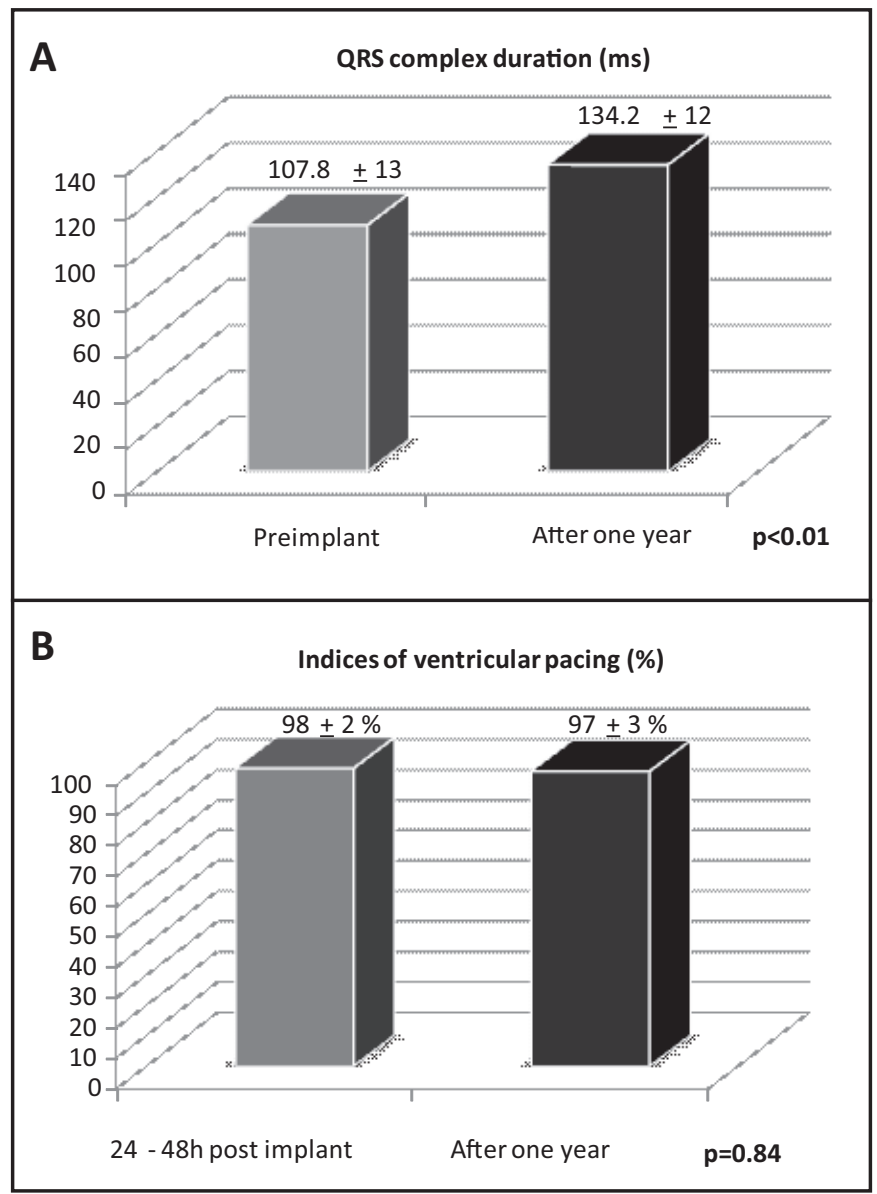

FIGURE 2 - A: Comparison of QRS complex duration before preimplantation and after a year of cardiac pacing. B: The stimulation indices in the ventricular pacemaker channel.

TABLE 1 - Parameters of effort duration and estimated oxygen consumption during exercise testing.

\begin{tabular}{|c|c|c|c|}
\hline \multirow[b]{2}{*}{ Variables } & \multicolumn{2}{|c|}{ Time of evaluation } & \multirow[b]{2}{*}{$\mathbf{p}$} \\
\hline & one month post implant & after one year follow-up & \\
\hline Exercise duration (min) & $12.51 \pm 2$ & $12.37 \pm 2$ & 0.83 \\
\hline Estimated VO2 $\max (\mathrm{ml} / \mathrm{Kg} / \mathrm{min})$ & $30.14 \pm 3$ & $29.83 \pm 3$ & 0.71 \\
\hline
\end{tabular}

VO2: maximum oxygen consumption. 
TABLE 2 - Sample data and results of echocardiographic parameters.

\begin{tabular}{|c|c|c|c|}
\hline \multirow{3}{*}{$\begin{array}{l}\text { Variables } \\
\text { Number of patients }\end{array}$} & \multicolumn{2}{|c|}{ Time of evaluation } & \multirow[b]{3}{*}{$\mathbf{p}$} \\
\hline & 24 a $48 \mathrm{~h}$ post implant & After one year follow-up & \\
\hline & 30 & 30 & \\
\hline Age (mean) & \multicolumn{2}{|c|}{$59 \pm 13$ years-old } & \\
\hline LVEDD (mm) & $54 \pm 7$ & $55 \pm 7$ & 0.61 \\
\hline Ejection fraction (mean)\% & $62 \pm 5$ & $61 \pm 3$ & 0.75 \\
\hline $\mathrm{ESV}(\mathrm{ml})$ & $55.5 \pm 29$ & $56.9 \pm 21$ & 0.87 \\
\hline SPWMD (M mode) ms & $103.7 \pm 38$ & $105 \pm 39$ & 0.84 \\
\hline LVET (ms) & $138 \pm 34$ & $140 \pm 35$ & 0.81 \\
\hline LVET - RVET (ms) & $25.7 \pm 19$ & $27 \pm 19$ & 0.77 \\
\hline
\end{tabular}

LVEDD: left ventricle end-diastolic dimension; ESV: end-systolic volume; SPWMD: septal-toposterior wall motion delay; LVET: left ventricular pré-ejection time; RVET: right ventricular pré-ejection time.

\section{DISCUSSION}

For nearly 40 years since the advent of cardiac pacing, the right ventricular apex has been considered the preferred site for ventricular electrode implantation in conventional pacemakers. The assessment of damage caused by iatrogenic left bundle branch block produced by right ventricle unifocal pacing in cardiac pacemakers is a relatively recent concern ${ }^{35,38-42}$. The main harmful effects are as follows: increased iatrogenic intraventricular conduction delay; left ventricular electrical and mechanical dyssynchrony; left ventricular remodeling; myocardial histopathological changes; left ventricular dysfunction (systolic and diastolic); congestive heart failure; myocardial perfusion defects and changes in segmental mobility; functional mitral regurgitation; increased risk of atrial fibrillation, sinus node dysfunction and normal baseline QRS; left atrial enlargement; ventricular arrhythmias; and activation of the sympathetic nervous system.

Despite evidence from experimental and clinical studies, the harmful effects associated with right ventricle unifocal pacing depend on the interaction between factors specific to each patient, including basic atrial rhythm, atrioventricular and intraventricular intrinsic cardiomyopathy and LVET at baseline. Besides these, certain conditions are directly related to pacing, such as the stimulation site, the programming mode, paced QRS complex duration and the percentage and duration of pacing in the ventricular channel ${ }^{42}$.

Since the 1990s, alternatives to the RV apex position have been studied, based on the search for a more physiologically normal depolarization due to unifocal pacing ${ }^{43,44}$. However important limitations can be observed in the literature in relation to the small number of patients evaluated, lack of randomization in some reports, difficulty in standardizing the definition of criteria for alternative sites and different methods of assessing the impact on cardiac function ${ }^{45}$.

The electrocardiographic and radiological criteria used for septal implants are not as accurate, resulting in a heterogeneous group of different stimulation sites ${ }^{45}$. To make matters even more complicated, the narrowing of the QRS complex in the septal position compared to the RV apex, does not correspond to the improvement in clinical, functional and echocardiographic parameters in patient follow-up in some studies ${ }^{46,47}$.

Despite all the advances in cardiac electrotherapy over the last 50 years, right ventricle pacing is still not capable of substituting natural activation time through the specialized fibers of the His-Purkinje system. This limitation can be detrimental to cardiac function, particularly in patients with systolic dysfunction, and justifies the intensive search for strategies to minimize this harmful effect.

The number of Chagas disease patients submitted to pacemaker implants and replacement still represents a significant subgroup. Despite subestimated data, almost $25 \%$ of all devices used in Brazil over the past 15 years are associated with Chagas disease ${ }^{19}$, including $62 \%$ of the implants currently performed by the Cardiac Pacing Service of the CH-UFTM ${ }^{17}$.

Research concerning less harmful forms of cardiac pacing that do not contribute to the onset of and worsening heart failure or increased mortality is of paramount importance. So far, no evidence is available regarding the site of choice for right ventricular pacing in patients with Chagas disease.

Harmful effects of cardiac pacing have been reported, particularly in patients with systolic dysfunction. Hearts presenting no significant structural alterations and with preserved systolic function may be able to offset the negative impact of mechanical dyssynchrony ${ }^{48,49}$.

Analysis of the results obtained in this study reveal that septal stimulation in Chagas disease patients without heart failure show an increase in the duration of the QRS complex and association with intraventricular dyssynchrony in $46.6 \%$ of cases; moreover, interventricular dyssynchrony was detected in $33.3 \%$ of patients after one year of pacing. Despite these changes, no significant structural or functional effect was detected during the study period, such that the patients remained in functional class I, presented very similar exercise duration and $\mathrm{VO} 2$ max values in the ET and no echocardiographic variations consistent with left ventricular remodeling were quantified.

The findings of this study as refered to the presence of dyssynchrony and the degree of repercussion on the cardiac structure and function can be compared to other etiologies and using the apical pacing site. Similarly, despite the presence of left ventricular dyssynchrony, there was no appearance of left ventricular remodeling or worsening of physical capacity during follow-up in patients without heart failure ${ }^{48-50}$.

A study at the Heart Institute of São Paulo (INCOR-SP) in 2009 showed that after $8.4 \pm 6.4$ years of apical pacing the left ventricle (LV) dyssynchrony was detected in 25 (69.9\%) of 39 patients. However, no significant correlation between this variable and ventricular function or other clinical and echocardiographic characteristics was found ${ }^{49}$.

Similar results were observed by Oliveira et al. ${ }^{50}$ studying patients with congenital third-degree atrioventricular block with normal systolic function, underwent chronic apical pacing. Echocardiographic parameters indicative of dyssynchrony were detected in $31(57.4 \%)$ of 54 patients after $11.5 \pm 7.2$ years following pacemaker implantation. However, there wasn't significant correlation between the presence of dyssynchrony and left ventricular dysfunction.

The only description of the functional assessment of septal stimulation site in a similar population sample to the present study was carried out by Sa et al. ${ }^{48}$. In this study was not detected left ventricular dyssynchrony in eight months of monitoring. The septal stimulation was used in $75 \%$ of patients in the apical position and $25 \%$ 
of the remaining. The chagasic etiology was observed in 12 patients ( $75 \%$ of the sample). The low indices of dyssynchrony observed by these authors in comparison with other studies may be related to preferential use of the septal position.

However, despite the similar stimulated QRS duration (134ms), the present study couldn't reproduce the same results concerned the absence of dyssinchrony. One explanation for this difference is the limitation of validation criteria of the septal position. The confirmation of septal position depends on two-dimensional anatomic radiological criteria that can cause slight variations. There is the possibility of fixing the electrode in the central portion of the septum or in the transition to the free or anterior wall of the right ventricle. This variation can lead to further stimulation of the conduction system, generating QRS complexes wider and greater dyssynchrony or modify the sequence of cardiac activation. Anyway, a sample enlargement and increase in follow up to confirmation the results are need.

With regard to clinical findings, the results as observed by Sa et al. ${ }^{48}$ were similar of the present study. Despite the non-use of questionnaires on quality of life, this study showed that patients remained assyntomatic, kepping the functional class I (NYHA).

On the other hand, no significant changes were observed in functional capacity measured by exercise test in our sample. But, there was worsening in 6 min walk test in the study conducted by the gropu of Goiânia ${ }^{48}$. These results are consider conflicting, in view the equivalence between this two cited methods for assessment of aerobic capacity in patients with pacemakers ${ }^{51}$. It is a question that remains to be clarified and a long-term monitoring, as well as an sample increasing would contribut to settle this issue.

\section{Limitations of the study}

This study was conducted at a single center, involved a limited number of patients. It is necessary to confirm the findings in other services as well as studying a representative sample of the population of chagasic patients submitted to conventional pacemaker implantation.

Echocardiographic evaluation was not performed before pacemaker implantation so that prior electromechanical dyssynchrony associated with Chagas disease could not be determinated.

It's not possible to exclude the degenerative etiology (fibrosis of the conduction system) as an associated cause of the atrioventricular block in elderly patients (age $\geq 65$ years) with positive serology for Chagas disease.

The follow up of patients is relatively short and it is possible that cardiac structural changes with repercussions on the physical capacity may arise after a period of one year.

In conclusions, the findings of this work suggest that there is was not significant morphological and functional cardiac change following pacemaker implantation in right ventricular septal position in chagasic patients with normal ventricular function after one year follow-up. Thus, despite the widening of the QRS complex and the presence of electromechanical dyssynchrony, patients may remain asymptomatic, presenting unaltered functional capacity and no left ventricular remodeling. Nonetheless, a larger sample population and increased follow-up time are required to confirm these findings.

\section{CONFLICT OF INTEREST}

The authors declare that there is no conflict of interest.

\section{FINANCIAL SUPPORT}

FAPEMIG CDS-APQ-02657-2010. Prof. Dalmo Correia is a recipient of fellowship productivity from of the $\mathrm{CNPq}$.

\section{REFERENCES}

1. Chagas C. Nova Espécie mórbida do homem produzida por um Trypanossoma (Trypanossoma cruzi). Nota prévia. Gaz Méd Bahia 1909; 40:433-440.

2. Coura JR.Origem, determinantes e morbidade da doença de Chagas. Rev Facultad Ciencias Salud 2007; 2 (suppl I): 62-66.

3. Dias JCP. Globalização, iniqüidade e doença de Chagas. Cad Saude Publica 2007; 23:(supl I): 13-22.

4. Cadavid DIV. Atualização: marcapasso na doença de Chagas. Relampa $2008 ; 21: 87-91$.

5. Rassi Jr A, Rassi A, Little WC, Xavier SS, Rassi SG, Rassi AG, et al. Development and Validation of a Risk Score for Predicting Death in Chagas' Heart Disease. N Engl J Med 2006; 355:2488-2491.

6. Porto CC. Contribuição do eletrocardiograma no prognóstico e evolução da doença de Chagas, [Thesis]. [Belo Horizonte]: Faculdade de Medicina de Minas Gerais; 1963.

7. Lorga AM, Garzon SAC, Jacob JLB. Eletrograma do feixe de His na doença de Chagas crônica: localização e evolução do bloqueio atrioventricular. In: Davalos AR, editor. Enfermedad de Chagas. La Paz: Editorial Los Amigos del Libro; 1979: p. 433-452.

8. Rassi A, Rassi Jr A, Faria GHDC. História natural do bloqueio atrioventricular total de etiologia chagásica. Arq Bras Cardiol 1992; 59 (supl II):191.

9. Rincón LG. Análise do Perfil Clínico de Pacientes Chagásicos e não Chagásicos Portadores de Marcapasso Cardíaco. [Doctor Thesis]. [Belo Horizonte]: Faculdade de Medicina da Universidade Federal de Minas Gerais; 2003. 100 p.

10. Costa R, Rassi A, Leão MIP. Estudo clínico e epidemiológico de pacientes submetidos a implante de Marcapasso cardíaco artificial permanente: comparação dos portadores da doença de Chagas com os de doenças degenerativas do sistema de condução. Rev Bras Cir Cardiovasc 2004; 19:107-114.

11. Fiandras O. El primer marcapasso implantado em las Américas. Relampa 1994; 7.2:44-48.

12. Melo CS, Cardinalli Neto A, Silva LM, Carvalho EIJ, Lucatto LFA, Leite GMSL. Temas de Marcapasso. In: Melo CS, editor. Histórico da Estimulação Cardíaca Artificial. $3^{\text {rd }}$ ed. São Paulo: Casa Editorial Lemos; 2007. p. 29-63.

13. Dias JCP, Prata A, Correia D. Problems and perspectives for Chagas disease control: in search of a realistic analysis. Rev Soc Bras Med Trop 2008; 41:193-196.

14. Organización Panamericana de la Salud. Estimación cuantitativa de la enfermedad de Chagas en las Américas. Montevidéu, Uruguai: Organización Panamericana de la Salud; 2006.

15. Kanaan EE. Limiares de Comando e Sensibilidade Agudos e Crônicos em CabosEletrodos com e sem Liberação de Esteróides em Pacientes Chagásicos. Relampa 2005; 18:69-73.

16. Sá LAB, Rassi S, Ludovico MA. Efeitos da Estimulação Ventricular Convencional em Pacientes com Função Ventricular Normal. Arq Bras Cardiol 2009; 93:167-173.

17. Silva Jr O, Melo CS, Marra M, Tomaz AA, Pachon Mateos JC, Pachón Mateos JC. Estudo da Variação dos Parâmetros Eletrofisiológicos na Estimulação Ventricular Septal Direita em Chagásicos. Relampa 2007; 20:79-89.

18. Mora G, Echeverry MC, Rey GE, López MC, Posada LF, Rivas FA. Frequency of Trypanosoma cruzi infection in patients with implanted pacemaker. Biomedica 2007; 27:483-489.

19. Pachon MJC, Mosquera JAP, Pachon Mateos JC, Vargas RNA, Campos Neto $\mathrm{CM}$. Aspectos epidemiológicos da estimulação cardíaca no Brasil - $12^{\circ}$ ano do RBM - Registro Brasileiro de Marcapassos, Desfibriladores e Ressincronizadores Cardíacos. Relampa 2008; 21:5-12.

20. Furman S, Schwerdel JB. An intracardiac pacemaker for Stokes-Adams seizures. N Engl J Med 1959; 261:943-948. 
21. Auricchio A, Stellbrink C, Block M, Sack S, Vogt J, Bakker P, et al. Effect of pacing chamber and atrioventricular delay on acute systolic function of paced patients with congestive heart failure. The Pacing Therapies for Congestive Heart Failure Study Group. The Guidant Congestive Heart Failure Research Group. Circulation 1999; 99:2993-3001.

22. Pignalberi C, Ricci RP, Santini M. Deleterious effects of apical right ventricular stimulation. Should we change our method of pacemaker implantation? Ital Heart J 2005; 6:S635-S648.

23. Tantengco MVT, Thomas RL, Karpawich PP. Left ventricular dysfunction after long-term right ventricular apical pacing in the young. J Am Coll Cardiol $2001 ; 37: 39$.

24. Karpawich PP, Rabah R, Haas JE. Altered cardiac histology following apical right ventricular pacing in patients with congenital atrioventricular block. Pacing Clin Electrophysiol 1999; 22:1372-1377.

25. Thambo JB, Bordachar P, Garrigue S, et al. Detrimental ventricular remodeling in patients with congenital complete heart block and chronic right ventricular apical pacing. Circulation 2004; 110:3766-3772.

26. Tse HF, Yu C, Wong KK, Siu CW, Zhng XH, Ho WY, et al. Functional abnormalities with permanent right ventricular pacing. J Am Coll Cardiol 2002; 40:1451-1458

27. Pachón JCM, Pachón JC, Pachón EIM, Albornoz RN. Ventricular Pacemaker syndrome. Europace 2001; 2 (supll B): B136 abstract 772.

28. Manolis AS. The Deleterious Consequences of Right Ventricular Apical Pacing: Time to Seek Alternate Site Pacing. Pacing Clin Electrophysiol 2006; 29:298-315.

29. Silv a Jr O, Melo CS, Marra M, Correia D. Sítios Endocárdicos Alternativos na Estimulação Cardíaca Artificial. Arq Bras Cardiol 2011; 96:76-85.

30. Kormann DS, Jatene AD. Triângulo eletrodo-vértebro-diafragmático no posicionamento de eletrodo endocavitário para marcapasso cardíaco. Arq Bras Cardiol 1977; 39 (supl II):380.

31. Mazzocca G, Magni E, Venturini M, Fiaschi M, Pacchini M, Corbucci G. Septal Ventricular Stimulation With Standard Screw-In Leads. Europace 2005; 7 (suppl III):17

32. Molina L, Lara S, Limón F. Septal vs. Apical Pacing: A matter of Time. Europace 2005; 7 (suppl III):17.

33. Pachón Mateos JC, Pachón Mateos JC, Vargas RNA, Pachón Mateus EI, Pachón MZC, Lobo TJ, et al. Comparação dos Parâmetros Eletrofisiológicos das Estimulações Ventricular direita e Convencional e Septal. Relampa 2006; 19:231-237.

34. Burri H, Sunthorn H, Dorsaz PA, Viera I, Shah D. Thresholds and complications with right ventricular septal pacing compared to apical pacing. Pacing Clin Electrophysiol 2007; 30 (suppl I):75-78.

35. Tops LF, Schalij MJ, Bax JJ. The effects of right ventricular apical pacing on ventricular function and dyssynchrony implications for therapy.J Am Coll Cardiol 2009; 54:764-776
36. Kaye G, Stambler BS, Yee R. Search for the optimal right ventricular pacing site: design and implementation of three randomized multicenter clinical trials. Pacing Clin Electrophysiol 2009; 32:426-433.

37. Lieberman R, Grenz D, Mond HG, Gammage MD. Selective Site Pacing. PACE 2004; 27:883-886.

38. Occhetta E, Bortnik M, Marino P. Permanent Parahisian Pacing. Indian Pacing Electrophysiol J 2007; 7:110-125.

39. O'keefe JH, Abuissa H, Jones PG. Effect of chronic right ventricular apical pacing on left ventricular function. Am J Cardiol 2005; 95: 771-773.

40. Karpawich PP, Rabah R, Haas JE. Altered cardiac histology following apical right ventricular pacing in patients with congenital atrioventricular block. Pacing Clin Electrophysiol 1999; 22:1372-1377.

41. Vernooy K, Verbeek XA, Peschar M, Prinzen FW. Relation between abnorma impulse conduction and heart failure. J Interv Cardiol 2003; 16:557-562.

42. Siu CW, Wang M, Zhang XH, Lau CP, Tse HF. Analysis of ventricular performance as a function of pacing site and mode. Prog Cardiovasc Dis 2008; 51:171-182.

43. Gammage MD. Base over apex: does site matter for pacing the right ventricle? Europace 2008; 10: 572-573.

44. Francis JB, Jayesh B, Ashishkumar M, Faizal A, Harry Mond H. Right Ventricular Septal Pacing: Has it come of age? Indian Pacing Electrophysiol J 2010; 10:69-72.

45. Ng AC, Allman C, Vidaic J, Tie H, Hopkins AP, Leung DY. Long-term impact of right ventricular septal versus apical pacing on left ventricular synchrony and function in patients with second- or third-degree heart block. Am J Cardiol 2009; 13:1096-1100.

46. Prinzen F, Peschar M. Relation between the pacing induced sequence of activation and left ventricular pump function in animals. Pacing Clin Electrophysiol 2002; 25:484-498.

47. Cano O, Osca J, Sancho-Tello MJ, Sánchez JM, Ortiz V, Castro JE, et al Comparison of Effectiveness of Right Ventricular Septal Pacing Versus Right Ventricular Apical Pacing. Am J Cardiol 2010; 105:1426-1432.

48. Sá LAB, Rassi S, Ludovico MA. Efeitos da Estimulação Ventricular Convencional em Pacientes com Função Ventricular Normal. Arq Bras Cardiol 2009; 93:167-173.

49. Oliveira Jr RM, Costa R, Martinelli FM, Silva RT, Silva KR, Coimbra VG, et al Dissincronia ventricular eletromecânica em pacientes submetidos à estimulação crônica do ventrículo direito devido a bloqueio atrioventricular congênito (BAVTc). Arq Bras Cardiol 2009; 93 (supll I):95

50. Costa R, Leão MIP, Mori RF, Silva KR, Santos FA, Silva RT, et al. Dessincronia ventricular eletromecânica em pacientes com bloqueio atrioventricular adquirido submetidos a estimulação crônica do ventrículo direito. Arq Bras Cardiol 2009; 93 (supll I):96.

51. Sousa LAP, Britto RR, Ribeiro AL, Baracho SM, Costa VBV, Carvalho VT, et al. Six-minute walk test in patients with permanent cardiac pacemakers. J Cardiopulm Rehabil Prev 2008; 28:253-257. 